OPEN ACCESS

Edited by:

Haldre S. Rogers, lowa State University, United States

Reviewed by:

Ben T. Hirsch

James Cook University, Australia Joseph Douglas Mandla White University of the Witwatersrand,

South Africa

Richard T. Corlett,

Xishuangbanna Tropical Botanical

Garden, Chinese Academy of

Sciences (CAS), China

*Correspondence:

Francisco E. Fontúrbel

fonturbel@gmail.com

Specialty section:

This article was submitted to

Population, Community,

and Ecosystem Dynamics,

a section of the journal

Frontiers in Ecology and Evolution

Received: 02 June 2021 Accepted: 24 November 2021

Published: 16 December 2021

Citation:

Cordero S, Gálvez F and

Fontúrbel FE (2021) Multiple

Anthropogenic Pressures Lead

to Seed Dispersal Collapse of the

Southernmost Palm Jubaea chilensis.

Front. Ecol. Evol. 9:719566.

doi: 10.3389/fevo.2021.719566

\section{Multiple Anthropogenic Pressures Lead to Seed Dispersal Collapse of the Southernmost Palm Jubaea chilensis}

\author{
Sebastián Cordero, Francisca Gálvez and Francisco E. Fontúrbel* \\ Facultad de Ciencias, Instituto de Biología, Pontificia Universidad Católica de Valparaíso, Valparaíso, Chile
}

Seed dispersal is a critical process for plant reproduction and regeneration. Successful recruitment depends on pre- and post-dispersal processes that complete a seed's journey until becoming a new plant. However, anthropogenic stressors may disrupt the seed dispersal process at some stages, collapsing plant regeneration and hampering its long-term persistence. The Chilean palm tree Jubaea chilensis is the southernmost and the only non-tropical palm species, which currently relies on the scatter-hoarding rodent Octodon degus for seed dispersal. We assessed seed fate by measuring predation and dispersal rates through experimental fieldwork in the Palmar de Ocoa site (located within La Campana National Park) and the Palmar El Salto. We also used previous reports on seed harvest and seedling herbivory to depict the whole J. chilensis seed dispersal process and assess the relative importance of different anthropogenic pressures. We asked the following questions: (1) What is the effect of human harvesting on J. chilensis recruitment? (2) Do native and exotic rodents predate J. chilensis seeds in the same way? and (3) Does post-dispersal herbivory matter? We found that J. chilensis fruits are harvested for human consumption, reducing pre-dispersal available seeds by removing about 23 tons per season. Then, post-dispersal seeds at the Ocoa palm grove are heavily predated by exotic (Rattus rattus) and native (Octodon spp.) rodents; only $8.7 \%$ of the seeds are effectively dispersed by Octodon degus. At Palmar El Salto, $100 \%$ of the seeds were predated by Rattus rattus, precluding further analysis. Finally, $70 \%$ of the seedlings were consumed by exotic herbivores (mainly rabbits), resulting in a success rate of $1.81 \%$. Only $7.9 \%$ of the surviving seedlings become infantile plants (4 year-old). Our assessment suggests that $\mathrm{J}$. chilensis has aging populations with very few young individuals in disturbed sites to replace the old ones. For those reasons, we suggest increasing its conservation category to critically endangered as land-use change is rapidly fragmenting and shrinking the extant $\mathrm{J}$. chilensis populations. We urge to take urgent actions to protect this relict palm, which otherwise may go extinct in the next decades.

Keywords: central Chile, exotic species, Jubaea chilensis, overharvesting, seed predation, extinction 


\section{INTRODUCTION}

Seed dispersal is an important process for plant reproductive success, playing a key role in the functioning and dynamics of communities (Traveset and Richardson, 2006; Corlett, 2017) as well as in maintaining biodiversity (Bascompte and Jordano, 2007; Valiente-Banuet et al., 2015). This mutualistic interaction benefits both parties, by providing food resources for animals, and promoting the colonization of new ranges and escaping from competing siblings for plants (Farwig and Berens, 2012). Plants are highly dependent on animals for seed dispersal in different biomes, with $90 \%$ of trees being dispersed by animals in tropical regions (Howe and Smallwood, 1982) and up to $60 \%$ in temperate regions (Willson et al., 1990). Seed dispersers facilitate natural plant regeneration. Therefore, the disruption of dispersal interactions can decrease gene flow among populations and limit seedling recruitment and establishment, leading to the collapse of regeneration and subsequent local extinction (Rodríguez-Cabal et al., 2007; Gomes et al., 2008; Aslan et al., 2013; Fontúrbel et al., 2019; Meadley-Dunphy et al., 2020).

Habitat alteration caused by anthropogenic activities usually induces changes in the composition of frugivorous animals that perform seed dispersal services (Figueroa-Esquivel et al., 2009; Vizentin-Bugoni et al., 2019). Disturbed habitats are more susceptible to being invaded by exotic animal species, interfering with ecological interactions such as seed dispersal and predation (Shiels et al., 2014). Sometimes exotic animals invade new habitats and establish novel interactions with native and exotic plants, altering seed dispersal, and recruitment patterns (Foster and Robinson, 2007; Devenish et al., 2019; Meadley-Dunphy et al., 2020). However, in many cases, exotic species behave like seed predators, limiting seed banks of native species (Towns et al., 2006; Stachurska-Swakon et al., 2018). In this regard, exotic rats (Rattus spp.) are important seed predators (Yabe et al., 2010) and are considered as one of the most harmful invasive species worldwide (Drake and Hunt, 2009). Rattus spp. are common in disturbed forests (Meyer and Shiels, 2009; Fontúrbel, 2012) and usually exert negative ecological impacts by acting as major seed predators, consequently affecting forest dynamics and composition (Campbell and Atkinson, 2002). These rodents may have been responsible for many past plant extinctions, as in native palm forests in Hawai'i (Athens et al., 2002) and Easter Island (Hunt, 2007).

Some relict plant species depend on rodents for seed dispersal, as is the case of Jubaea chilensis, an endangered palm species from central Chile. Although it is believed that the fruits of J. chilensis were dispersed by extinct megafaunal species in the past (González et al., 2017), its seeds are currently dispersed by the native scatter-hoarding rodent Octodon degus. Scatterhoarding behavior implies that uneaten seeds can germinate under beneficial conditions, but many seeds are destroyed when the embryo is damaged (Vander Wall, 1990; Lichti et al., 2017). This scatter-hoarder rodent uses palm seeds as a key resource during juvenile and pre-reproductive stages (Zunino et al., 1992). However, this interaction is disrupted by the black rat (Rattus rattus), a major palm seed predator (Perez et al., 2008; Maron and Pearson, 2011).
Jubaea chilensis is the southernmost palm tree, endemic to continental Chile, and the only species of the monotypic genus Jubaea (Arecaceae), whose populations from the Easter Island became extinct in the sixteenth century presumably due to seed predation by Pacific rats (Rattus exulans). Although this palm species was highly abundant in the past, its presence is currently restricted to three main populations within protected areas and some private lands in central Chile (FloresToro and Aguirre-Saavedra, 2008). Thus, it is considered as Vulnerable according to the IUCN threat categories. During the last decades, J. chilensis populations have suffered a substantial decline as a consequence of multiple anthropogenic pressures, which include fruit and seed overexploitation for human consumption, reduction of vegetation cover, wildfires, and exotic species (González et al., 2009; Guzmán et al., 2017). However, the impacts of exotic species may be largely underestimated as they are usually associated with herbivory by lagomorphs and domestic cattle. Therefore, the ecological consequences of seed predation by exotic rodents remain largely unknown. Here we assessed the whole seed dispersal process (from fruits to seedlings) of the largest J. chilensis population, related to different anthropogenic stressors that may lead to a reproductive collapse in this species, we used camera-trap monitoring, experimental field tests, and demographic information gathered from previous reports to answer the following questions: (1) What is the effect of human harvesting on J. chilensis recruitment? (2) Do native and exotic rodents predate J. chilensis seeds in the same way?, and (3) Does post-dispersal herbivory matter? We hypothesized that J. chilensis recruitment would be negatively affected by multiple anthropogenic stressors, being seed predation by rodents the most critical factor.

\section{MATERIALS AND METHODS}

\section{Study Area}

The study was conducted at the Palmar de Ocoa site, located

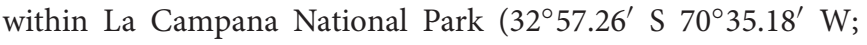
Figure 1). This public protected area is located in the mountain range of La Campana-El Roble, in the Valparaíso region (central Chile). The study area is encompassed in the Central Chile biodiversity hotspot (Myers et al., 2000), characterized by a Mediterranean climate type, with rainy winters reaching around $480 \mathrm{~mm}$ annually and a prolonged dry period with only $120 \mathrm{~mm}$ of rain (Quintanilla et al., 2012). The average annual temperature is $\sim 18^{\circ} \mathrm{C}$ (Pliscoff, 2009). This site contains the largest J. chilensis population with $\sim 70,000$ individuals (including all age classes) (Gallardo et al., 2006; González et al., 2009, 2017). The dominant vegetation is composed of sclerophyllous forests and scrubland formations, where J. chilensis is mainly associated with Cryptocarya alba, Quillaja saponaria, Lithrea caustica, Peumus boldus, and Retanilla trinervia. Further, the Santuario de la Naturaleza Palmar El Salto (Palmar El Salto hereafter; $33^{\circ} 04.00^{\prime} \mathrm{S} 71^{\circ} 31.00^{\prime} \mathrm{W}$ ) is a protected site that contains the third-largest $J$. chilensis population with $\sim 7,000$ individuals (Flores-Toro and Aguirre-Saavedra, 2008), which we 


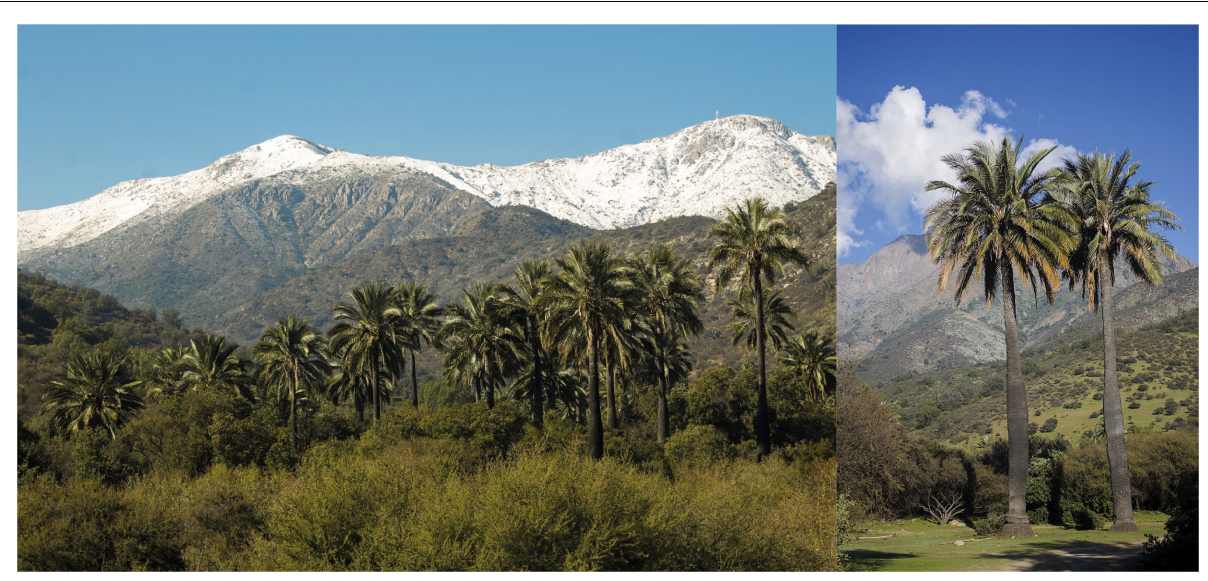

FIGURE 1 | A panoramic view of the Ocoa palm grove (left panel) and a Jubaea chilensis adult individual (right panel).

also studied for comparison purposes. This site is fragmented into four areas: Rodelillo, Altos del Tranque, Quebrada El Quiteño, and Quebrada Las Siete Hermanas; the latter was selected for the study as it is the one with the highest number of J. chilensis individuals (Möder et al., 1997). The vegetation at Palmar El Salto is represented mainly by scrubland formations, dominated by Nassella chilensis, Chusquea cumingii, and Retanilla trinervia (Flores-Toro and Aguirre-Saavedra, 2008). This study area is characterized by a Mediterranean climate with coastal influence and annual precipitation of up to $400 \mathrm{~mm}$ (Flores-Toro and Aguirre-Saavedra, 2008). Despite the fact there is a protected site, it was not designated for preservation and conservation purposes; thus, multiple anthropogenic pressures as domestic cattle, frequent intentional fires, and fruit extraction are some of the greatest threats to this J. chilensis metapopulation.

\section{Demography}

Based on the latest available censuses reported by González et al. (2017) and Bravo et al. (2018), the current J. chilensis population at the Palmar de Ocoa, within La Campana National Park, comprises 70,308 individuals. From those, 31,143 individuals belong to reproductive adults (75-250 years; $44.3 \%)$, 7,078 to juveniles (35-75 years; $10.1 \%$ ), 2,359 to infantile (435 years; $3.4 \%$ ), and 29,728 to seedlings ( $<4$ years; $42.3 \%$ ) (accordingly to the 2017 census of Bravo et al., 2018). On the other hand, the J. chilensis population at the Palmar El Salto comprises 6.947 individuals, with 6,441 individuals belonging to reproductive adults (92.7\%), 504 to juveniles $(7.8 \%), 2$ to infantile $(0.03 \%)$, and 0 to seedlings $(0 \%)$ (accordingly to the census of González et al., 2017). Age classes were defined following the criteria of González et al. (2017). Fruiting on $J$. chilensis occurs on palm trees of at least 75 years old (González et al., 2017) producing $\sim 10,000$ fruits per palm (information obtained from Guzmán et al., 2017). On average, the seed germination rate is $\sim 70 \%$, but it may take up to 4 years as these seeds have a long dormancy period (Guzmán et al., 2017).

\section{Seed Dispersal and Predation Assessment}

During the austral fall of 2018 (March-May, corresponding to the J. chilensis fructification period), we installed feeding stations (25 in the Palmar de Ocoa and 5 in the Palmar El Salto) under breeding palm individuals (palm seeds naturally fall and can be found in the ground, but now they are particularly scarce due to human harvesting practices), separated by at least $100 \mathrm{~m}$ from each other to ensure independence. We used seeds because (i) fruits are extremely scarce in palm groves due to anthropogenic harvesting pressures, and (ii) rabbits usually consume the remaining pulp, modifying seed arrangement and making it impossible to recognize seed identity afterward. The J. chilensis fruits are yellowish-green ovoid monospermous drupes of $4-\mathrm{cm}$ in diameter, which fall from the palm when ripe and release the seeds when dehydrated. When the pulp is not completely detached from the seed, rabbits sometimes eat it, leaving bare seeds intact in the site; contrarily, rodents remove pulp and discard it to obtain the seeds.

Each feeding station contained 24 palm seeds, provided by the Hacienda Las Palmas de Cocalán, due to the fruit scarcity and difficulty obtaining intact seeds within the study area. Seeds were marked by attaching a $65-\mathrm{cm}$ nylon thread using epoxy glue, with a $15-\mathrm{cm}$ adhesive tape attached to the distal end, containing a unique identification code in indelible ink. We placed those 24 seeds in a correlative numerical order at each station along a circle with the labels facing outward. The first seed was pointed as a reference to identify the complete set of seeds. Tags were covered with litter from the surrounding area to make them less visible. Then, to assess seed removal by rodents, we used infrared camera traps (Browning Strike Force HD Pro) placed 10-20 cm above the ground and $1.5 \mathrm{~m}$ away from the feeding station and separated at least $100 \mathrm{~m}$ from each other to minimize data independence problems. Camera traps were operated in video mode with 20-s captures and a 10-s delay between captures. After the depletion of the stations, we conducted exhaustive searches for labels in a 40 -m radius on days $2,4,6,8,16$, and 32 , verifying and recording seed destination. Post-removal seed destination was classified as: 
(i) cached, if the seed was buried intact, (ii) eaten, if threads were still attached to seed fragments or if fragments were found near the tags, and (iii) unknown fate, if not found the label within the study area (those seeds were excluded from the analysis).

\section{Data Analysis}

We used a sequential analysis from fruit production to seedling survival. We used the demographic information described in section "Demography" (information obtained from previous reports) and the seed dispersal and predation information obtained through the camera-trap assessment (described in section "Seed Dispersal and Predation Assessment"). We compared seed fate (either disperser, eaten, or missed) data for each rodent species detected by our camera traps using one-way ANOVAs and Tukey post hoc tests. We were able to make such comparisons only for the Palmar de Ocoa site, as at Palmar El Salto, all seeds were eaten by a single species, precluding any comparison. Further, we estimated the impact of human harvesting using information from the Chilean Ministry of Environment (Gallardo et al., 2014), which reports that 200 people were authorized to extract $J$. chilensis fruits during the masting period, such extraction represents $\sim 23$ tons of fruits per year [we estimated the number of fruits using the average mass of the seeds (7.66 g) used for the camera-trap assessment]. Then, we used the average germination rate reported by Guzmán et al. (2017) to estimate the number of seedlings produced. Seedlings are known to be largely affected by exotic herbivores in the study area (Guzmán et al., 2017). Therefore, to estimate the final number of surviving seedlings, we used sapling herbivory estimations from Cabello (2006), which were around $70 \%$ and mainly caused by rabbits and cows (Marcelo, 2007). Finally, we estimated the overall success rate as the ratio between the number of surviving seedlings and the number of seeds produced.

\section{RESULTS}

We obtained valuable information on Jubaea chilensis demography and seed dispersal from different data sources (Table 1). We used the data of the Palmar de Ocoa site, which has 70,308 Jubaea chilensis individuals according to the last census (González et al., 2017). Of those individuals, 44.3\% correspond to breeding adults, representing 31,143 individuals. Considering that each adult palm can produce 10,000 fruits on average, the overall number of seeds produced (considering that these are single-seeded fruits) is $311,430,000$.

\section{Human Harvesting Impact}

From the 311,430,000 fruits produced per year, human harvesting (the main pre-dispersal threat) is responsible for extracting $3,002,611$ fruits -based on official reports from the Ocoa palm grove- stating that 23 tons of $J$. chilensis fruits are extracted each year (average seed mass $7.66 \mathrm{~g}$ ). Thus, human harvesting equals depleting $\sim 300 \mathrm{~J}$. chilensis individuals, leaving 308,427,389 seeds (99\%) to be dispersed (Figure 2A). There are no official records of fruit extraction for the Palmar El Salto site.
TABLE 1 | Data sources of the seed dispersal variables included in this study.

\begin{tabular}{lcc}
\hline Stage & Variable & Sources \\
\hline Pre-dispersal & Fruit production & Guzmán et al., 2017 \\
& Seed harvest & Gallardo et al., 2014 \\
& Population census & Bravo et al., 2018 \\
Dispersal & Age structure & González et al., 2017 \\
& Seed predators & Our camera trap data \\
Post-dispersal & Seed dispersers & Our camera trap data \\
& Germination rate & Our camera trap data \\
& Herbivory rate & Guzmán et al., 2017 \\
\hline
\end{tabular}

\section{Seed Predation and Dispersal Patterns}

We found three rodent species feeding on J. chilensis seeds in our camera trap records at the Palmar de Ocoa (Figure 3). From the total 596 photographic records -obtained from 25 independent camera traps- 236 corresponded to the exotic black rat (Rattus rattus; 39.6\%), 232 corresponded to the native nocturnal rodent Octodon lunatus (38.9\%), and 128 corresponded to the native diurnal rodent Octodon degus $(21.5 \%)$. Some camera traps recorded visitation events of a single rodent species, while others recorded two or three species within the same station. All seeds placed in the experimental stations were depleted within 1 week. Both $R$. rattus and O. lunatus acted only as seed predators, with 213 seeds (91.8\%) eaten (i.e., predated) and $23(8.2 \%)$ with unknown fate in the case of $R$. rattus, and 200 seeds $(86.2 \%)$ eaten and $32(13.8 \%)$ with unknown fate in the case of O. lunatus (Figure 4). However, O. degus had a dual role as seed disperser and predator. From the 128 seeds collected by O. degus, 71 (55.5\%) were eaten, 46 (35.9\%) were effectively dispersed (no larder-hoarding was observed at our study site), and we were unable to determine the fate of 11 $(8.6 \%)$ seeds. Seeds were dispersed at distances of $6.2 \mathrm{~m} \pm 0.4$ (mean \pm standard error; range: 1.0-20.3). Therefore, $91.32 \%$ of the seeds with known fate were predated, while only $8.7 \%$ of the seeds $(15,545,653)$ represent $8.5 \%$ of the seeds produced and $8.68 \%$ of the seeds available post-harvesting) were effectively dispersed by $O$. degus (Figure 2B). By extrapolating these values to the population, $15,545,653$ seeds may be effectively dispersed, representing $8.5 \%$ of the seeds produced and $8.68 \%$ of the postharvesting seeds. In the case of the Palmar El Salto, the only rodent species present was $R$. rattus, which depleted feeding stations within $48 \mathrm{~h}$. From the 120 seeds placed there, 118 (98\%) were predated by $R$. rattus, and two were missed (2\%) after rodents removed them.

\section{Germination and Seedling Herbivory}

Assuming an average germination rate of $70 \%$ (values obtained from previous reports), the 26,771,497 seeds would yield $18,740,048$ seedlings. From those, $70 \%$ is lost by exotic herbivores (the main post-dispersal threat according to the published literature), leaving only 5,622,014 seedlings that may be capable of surviving and recruiting to the population. Therefore, these figures represent a success rate of $1.81 \%$ (Figure 2C). Furthermore, following the population age structure from the last 


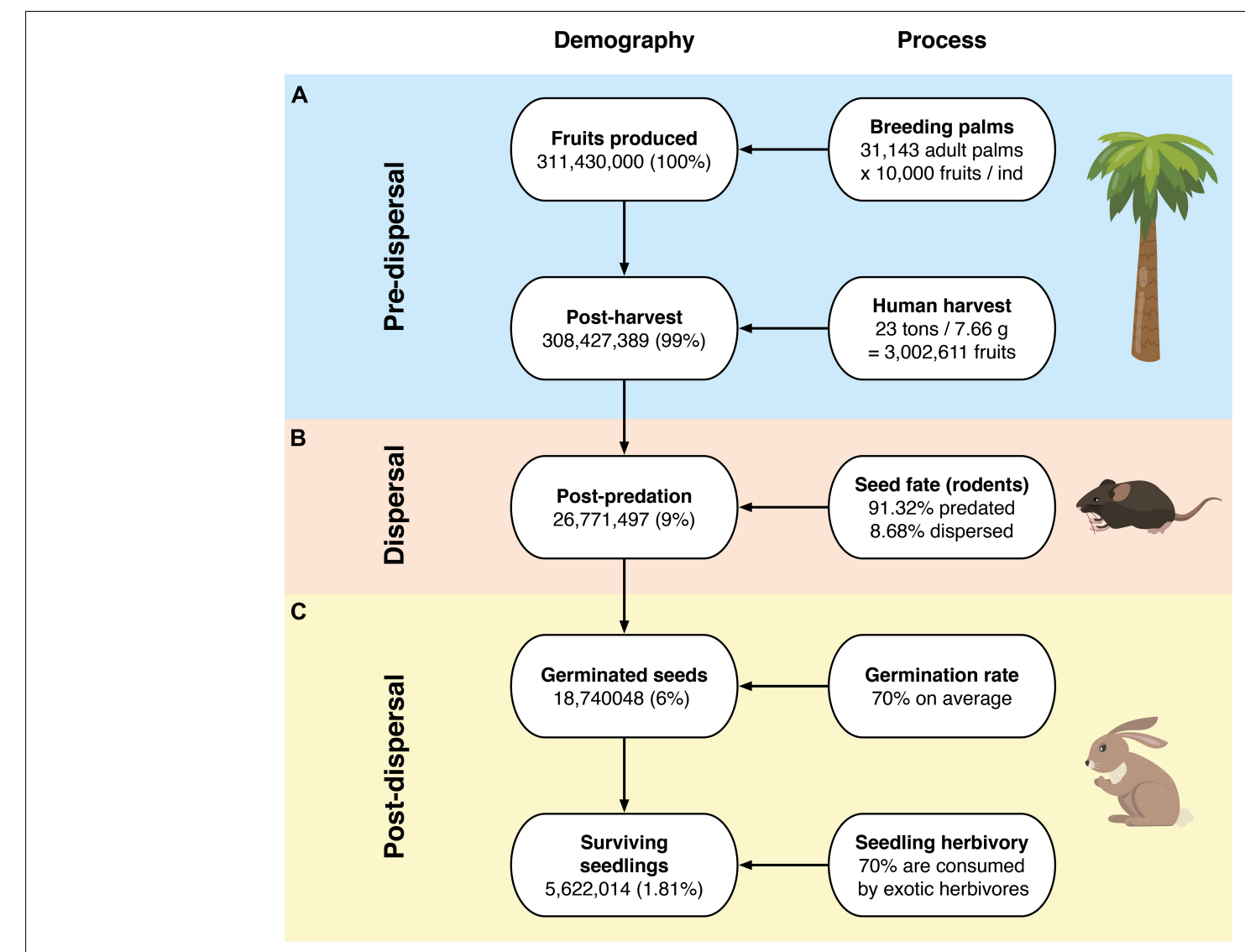

FIGURE 2 | Jubaea chilensis recruitment process at: (A) pre-dispersal, (B) dispersal, and (C) post-dispersal stages.

census (Bravo et al., 2018), only 7.9\% of the seedlings will survive until the fourth year to become infantile individuals, resulting in 444,139 potential recruits (equivalent to $0.14 \%$ of the total fruits produced). We could not perform a similar analysis for the Palmar El Salto site, as there is no regeneration at this site.

\section{DISCUSSION}

We found that the Jubaea chilensis seed dispersal process is affected by anthropogenic stressors at all stages of recruitment. This chain of events begins with human harvesting, which acts at the pre-dispersal stage. Although local people remove 23 tons of fruits each year, it only represents $\sim 1 \%$ of the fruits produced by the adult palms in our study area. However, those numbers may be underestimated for two reasons. First, our estimations are based on official extraction reports (based on management plans with extraction quotas defined a priori). However, some illegal extraction cannot be quantified and it is expected to vary over the years. Second, besides fruit extraction, people also extract palm sap to produce a sweet syrup commonly called "palm honey." González et al. (2009) indicate that up to $400 \mathrm{~L}$ of sap can be extracted from each palm tree, but the actual sap extraction values are unknown as no management plan is associated with this kind of use. While sap extraction does not kill the palm, it is likely to impact fruit production, but those effects have not been quantified yet. There are official reports of fruit extraction at our site because it is a public, protected area. However, quantitative data is largely absent from other localities where we found remnant palm populations.

Examining the next phase of the seed dispersal process, we found that seed predation is by far the most relevant threat for J. chilensis regeneration. Currently, J. chilensis seed dispersal relies on the native rodent Octodon degus, responsible for dispersing about half of the seeds caught by scatterhoarding (i.e., burying the seeds) and eating the other half. However, its close relative, O. lunatus, predate all seeds taken as this species does not bury seeds for consuming them later (Zunino et al., 1992; Kelt et al., 2004). Besides those two native rodents, the exotic Rattus rattus is a common invasive species in this area responsible for predating $\sim 34 \%$ of the seeds (236 out of 696 seeds). The proliferation of Rattus spp. is positively associated with habitat disturbance (Cusack et al., 2015), becoming major seed predators across different ecosystems (Campbell and Atkinson, 2002; Hunt, 2007; Yabe et al., 2010; Shiels and Drake, 2011). In this regard, native vegetation of central Chile has been largely impacted by habitat fragmentation and degradation process, derived from a rapid land-use change (Echeverría et al., 2006, 2007), which may explain the increasing abundances of exotic rats to the detriment 


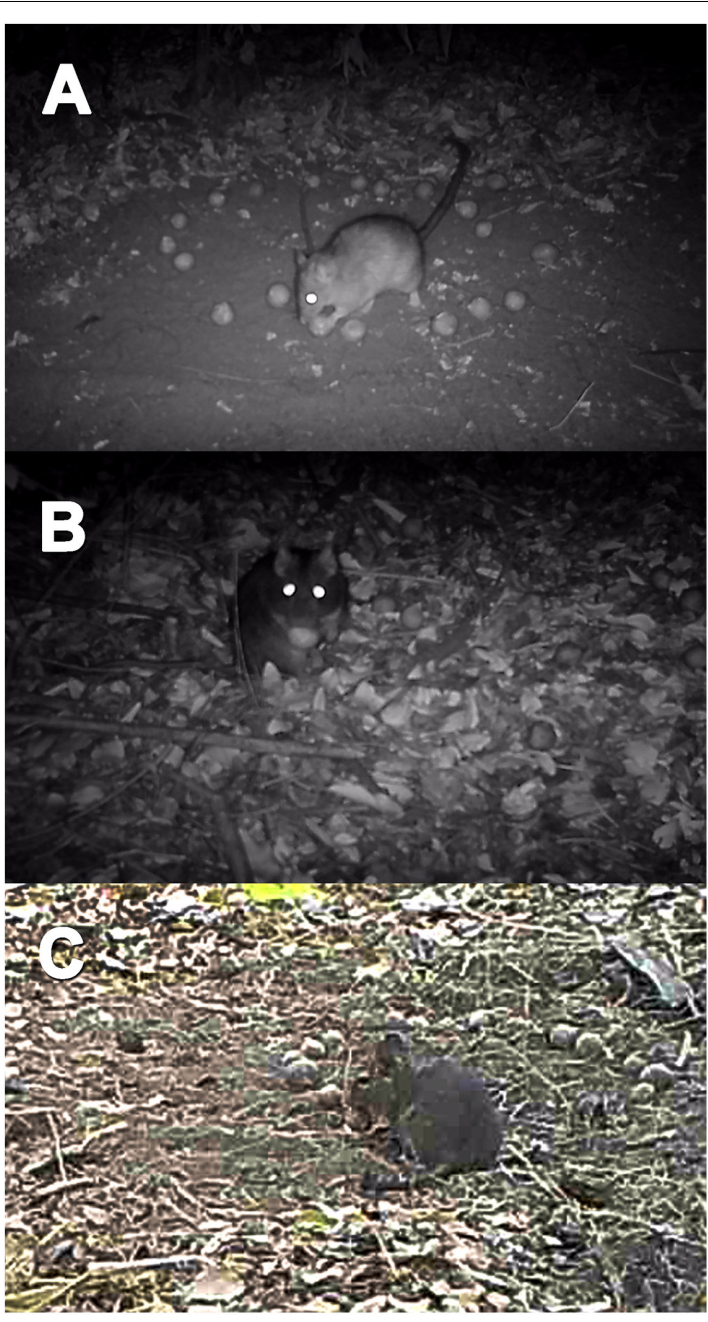

FIGURE 3 | The three rodent species consuming Jubaea chilensis seeds found during the camera-trap survey: (A) Rattus rattus, (B) Octodon lunatus, and (C) Octodon degus.

of native small mammals (Fontúrbel, 2012). Large Rattus rattus densities have been reported in the extant J. chilensis populations nearby urban centers of Valparaíso and Viña del Mar (i.e., Palmar El Salto site), largely subsidized by palm fruits and favored by the neighboring urban habitats. To the best of our knowledge, no other native seed disperser J. chilensis seeds besides Octodon degus, which could compensate for seed predation if exotic rodents were eventually removed, and no pathogens have been reported to affect seed viability. Thus, there is reasonable to assume that exotic rodents are responsible for limiting seed dispersal.

Although low seed dispersal rates may allow plant regeneration, limited dispersal can lead to alterations and collapse gene flow, affecting population connectivity, as well as the regional-scale distribution of genetic variation (PérezMéndez et al., 2018). This is a major threat for J. chilensis since current populations have been affected by genetic erosion and high levels of inbreeding, with populations as different genetic

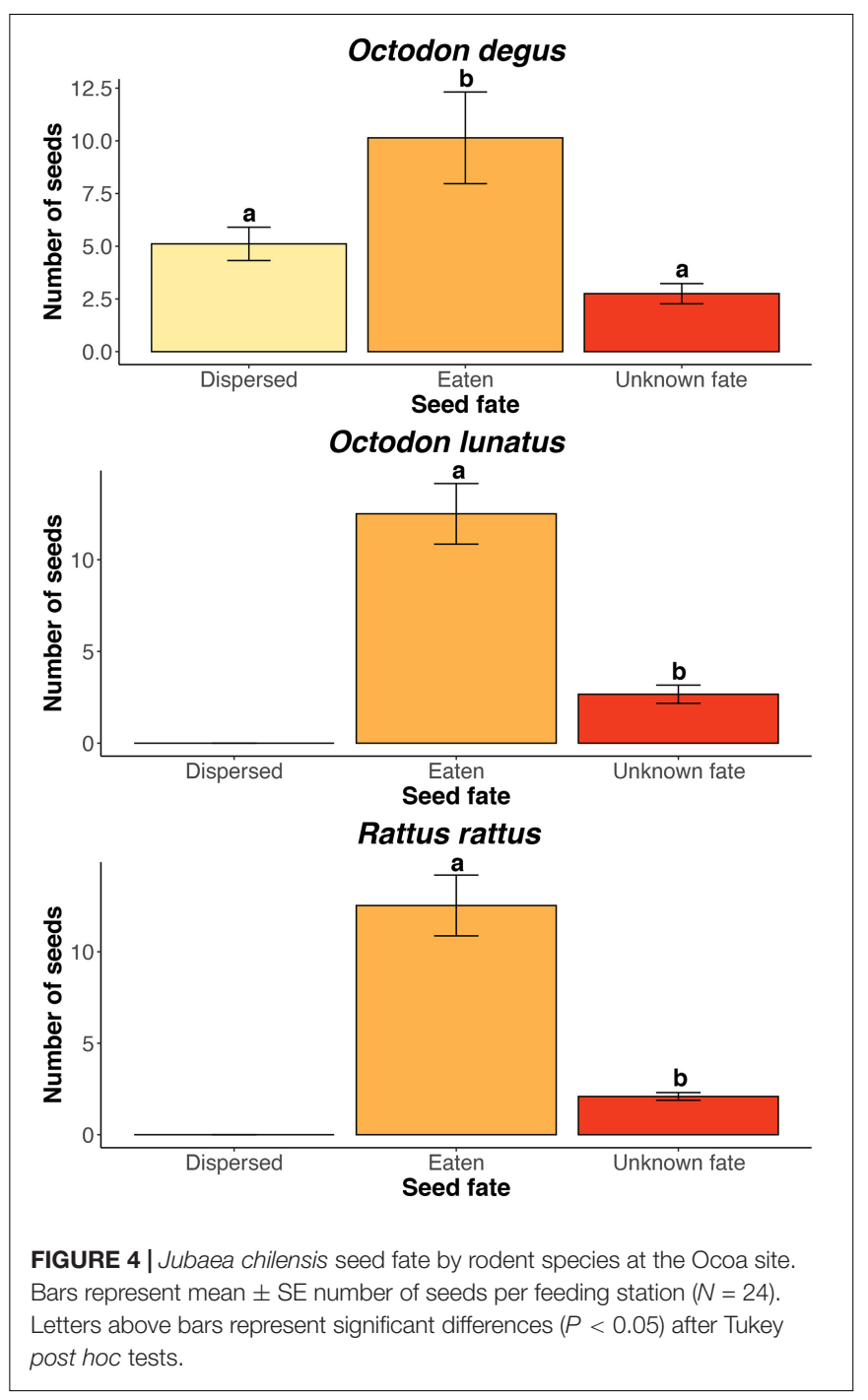

pools and loss of genetic variability (González et al., 2017). Therefore, the reduced genetic diversity of J. chilensis populations caused by limited dispersal and habitat fragmentation may reduce the ability of the species to persist under land use change and climate change scenarios.

Then, in the post-dispersal process, those few seeds effectively dispersed by $O$. degus must face two additional filters. The first filter is germination, as $J$. chilensis has slow germination. The seeds suffer a physiological dormancy due to the immaturity of the embryo, and germination takes up to 4 years (Guzmán et al., 2017). Within this period, seeds can be predated, reducing actual germination rates. Also, seeds can be re-cached, reaching sites with more suitable or unsuitable conditions for germination and can be pilfered by other rodents as well (Zhang et al., 2014). In the latter scenario, pilfered buried seeds may have a fate different than germination, as both $O$. lunatus and $R$. rattus act as seed predators. While the average germination rate is $\sim 70 \%$ (Cabello, 2006), microclimatic conditions largely influence it (Fleury et al., 2015). Seeds covered by a thick litter layer have larger germination rates 


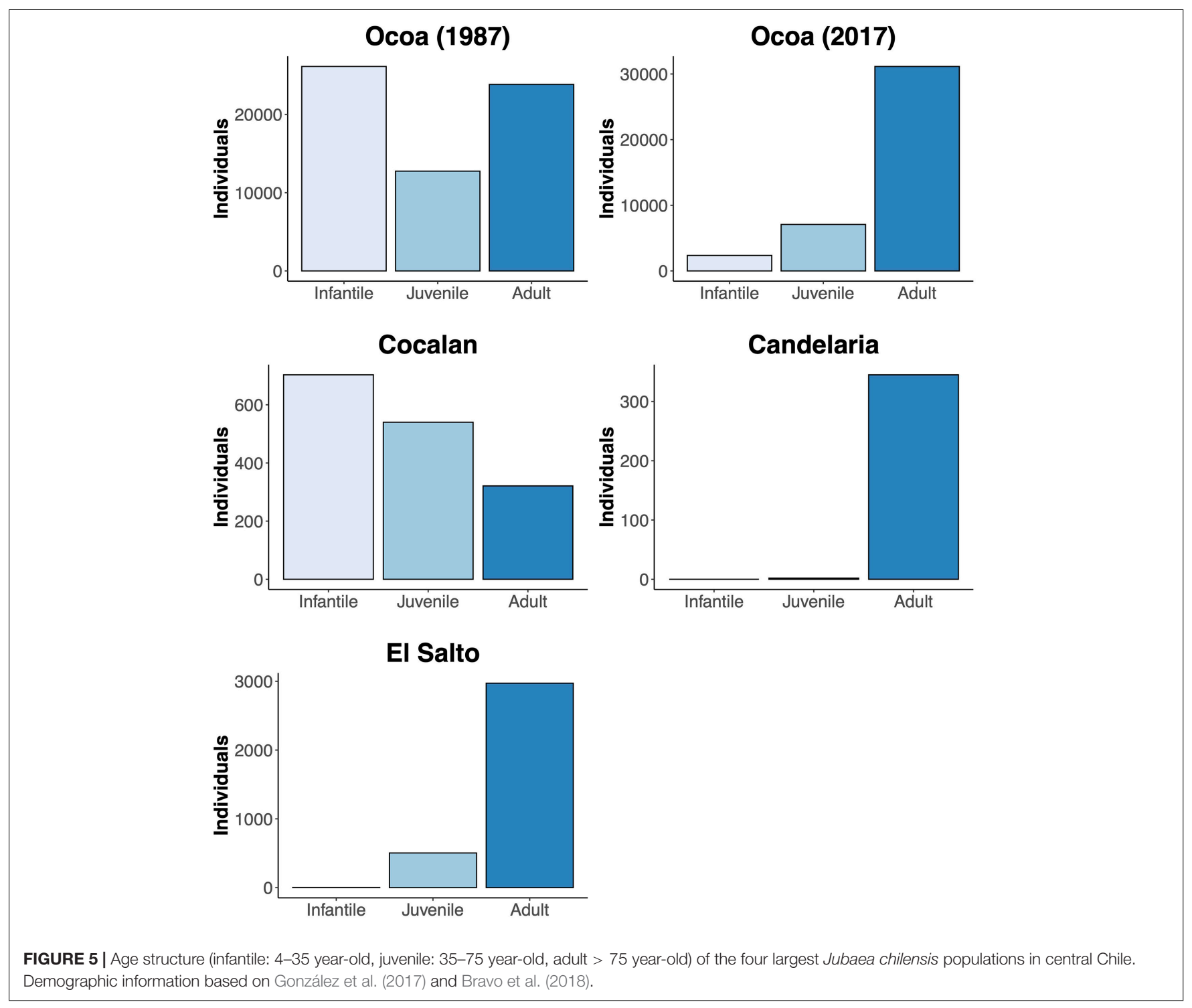

and seedling survival rates (Miranda et al., 2016). Also, denser native vegetation protects seedlings from abiotic stress and animal consumption, increasing their survival probabilities (Fleury et al., 2015). Thus, the fragmentation and degradation of the native sclerophyllous scrublands that characterize the extant J. chilensis remnants facilitate the invasion by exotic rats and reduce germination and seedling survival probabilities. Along with rats, other exotic species have intentionally and unintentionally been introduced to the study area and the proliferation of human settlements. Hence, rabbits and cows are very common herbivores in palm grove fields and, at the Palmar de Ocoa, are responsible for $\sim 70 \%$ of seedling mortality. An experiment conducted by Fleury et al. (2015) showed that excluding exotic herbivores increased seedling survival by $39 \%$. Also, herbivores consume other plant species that act as nurse plants for J. chilensis seedlings (Holmgren et al., 2000; Saiz and Alados, 2012), worsening the current scenario. Even if seedlings escape herbivory, infantile individuals are still subject to other anthropogenic pressures such as fire regimes, as they cannot cope with these events, unlike adults (González et al., 2017). Considering the pre-dispersal, dispersal, and post-dispersal processes affecting J. chilensis recruitment, we estimated a success rate of $1.81 \%$, which is consistent with a recent regeneration estimation made by the Chilean Forestry Corporation (CONAF, public entity responsible for the La Campana National Park); based on 113 plots, palm regeneration was estimated to be $1.1 \pm 0.3 \%$ (Bravo et al., 2018). Those estimations were based on monitoring individuals and determining age classes in several plots, but the factors explaining that result were not quantified yet.

\section{Future Perspectives}

The extant 120,980 J. chilensis individuals reported by González et al. (2009) represent $\sim 2.5 \%$ of the original population (estimated that there were 5 million individuals by 1550 ; Hechenleitner et al., 2005). Once, the Valparaíso region was 


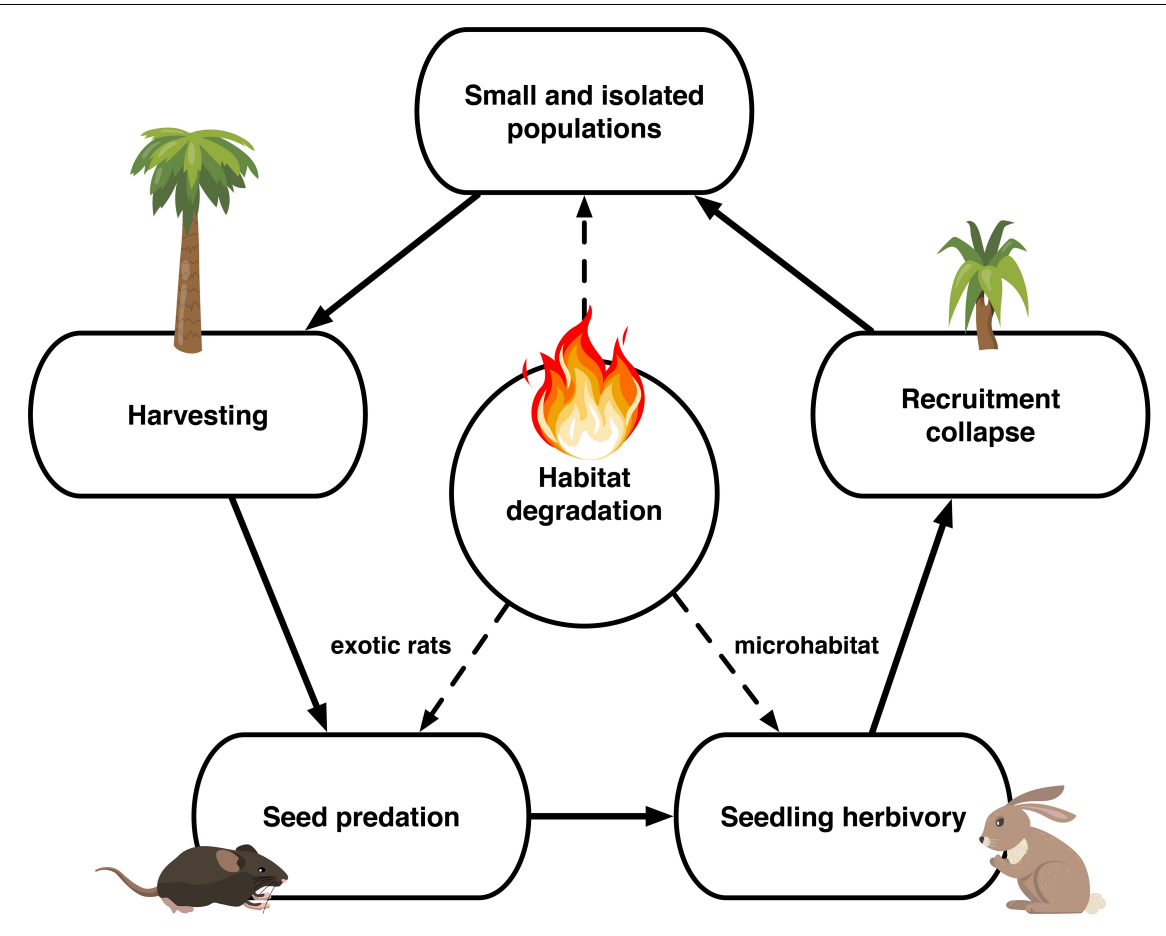

FIGURE 6 | Jubaea chilensis extinction process due to anthropogenic stressors affecting the seed dispersal process.

covered by dense palm groves, from which a few scattered populations remain. Of those, $87.5 \%$ are preserved within La Campana National Park (70,308 individuals) and Las Palmas de Cocalán National Park (35,500 individuals). The remaining 15,172 palm individuals are scattered among ten isolated populations, ranging between 2 and 7,200 individuals [mean abundance 1,664 \pm 729 individuals (mean $\pm 1 \mathrm{SE}$ )], and immersed in a heavily degraded anthropogenic matrix. Comparing the age classes of the four largest J. chilensis populations (Figure 5), we observe that the number of infantile and juvenile individuals in Ocoa has decreased between 1987 and 2017, while they are quite scarce at Candelaria and El Salto populations. The only exception is the Cocalán population, where infantile and juvenile individuals outnumber adult palms, which is because this site has a management plan for palm honey extraction that requires planting 10 new individuals for each adult palm harvested (Serra et al., 1986). Based on the evidence compiled and our data, we propose that currently, J. chilensis is undergoing through an extinction process (Figure 6) that can lead to a collapse in the next decades if no actions are taken.

Imposing harvesting quotas would have little impact on improving palm regeneration. What is urgent now is controlling exotic species that consume palm seeds and seedlings, collapsing its regeneration. Seed predation by rats and seedling herbivory by cows and rabbits occur even within protected area boundaries, putting the two largest $J$. chilensis populations at great risk (Fleury et al., 2015; Miranda et al., 2016). These extant palm groves can be considered as living dead because we have aging populations with little regeneration, facing increasing levels of anthropogenic disturbance. Thus, we may be witnessing an extinction debt here (Tilman et al., 1994; Carroll et al., 2004), as with the current recruitment levels, J. chilensis may become extinct within a century. Currently, this relict palm is categorized as Vulnerable by the International Union for Conservation of Nature (IUCN) red list. However, considering the facts presented here, we strongly suggest reconsidering such a category and changing it to Critically Endangered instead.

\section{CONCLUSION}

We conclude that the Chilean palm, Jubaea chilensis, is a critically endangered species due to the collapse of the seed dispersal process, hampering its recruitment. This is the southernmost palm species in the world, and the extant populations may represent an extinction debt. The anthropogenic pressures that this species faces may be leading to an inevitable collapse. We urge local authorities to take urgent actions to increase its protection and control those exotic species responsible for seed predation and seedling herbivory, which are the main recruitment decline drivers. The presence of exotic rats is positively correlated with habitat disturbance (Fontúrbel, 2012). Therefore, avoiding the degradation of the extant palm groves would be the best option to limit their populations. Furthermore, using exclusion meshes could significantly reduce rabbit herbivory on seedlings. However, the most relevant action would be to increase reforestation efforts by planting 4-yearold saplings since these are less susceptible to the potential damage caused by exotic herbivores. Together, these actions will 
contribute to recovering the extant populations and avoid a dark fate for this emblematic species.

\section{DATA AVAILABILITY STATEMENT}

Original data associated to this submission is available at the figshare digital repository: https://doi.org/10.6084/m9.figshare. 14717676.

\section{ETHICS STATEMENT}

Ethical review and approval was not required for the animal study because we only used camera-traps.

\section{AUTHOR CONTRIBUTIONS}

SC and FG conceived the study and collected field data. SC, FG, and FF designed the methodology. FF performed data analysis

\section{REFERENCES}

Aslan, C. E., Zavaleta, E. S., Tershy, B., and Croll, D. (2013). Mutualism disruption threatens global plant biodiversity: a systematic review. PLoS One 8:e66993. doi: 10.1371/journal.pone.0066993

Athens, J. S., Toggle, H. D., Ward, J. V., and Welch, D. J. (2002). Avifaunal extinctions, vegetation change, and polynesian impacts in prehistoric Hawai'i. Archaeol. Ocean. 37, 57-78. doi: 10.1002/j.1834-4453.2002.tb00507.x

Bascompte, J., and Jordano, P. (2007). Plant-animal mutualistic networks: the architecture of biodiversity. Annu. Rev. Ecol. Evol. Syst. 38, 567-593. doi: 10. 1146/annurev.ecolsys.38.091206.095818

Bravo, P., Castro, L., Martínez, M., and Pérez, I. (2018). Avances en el monitoreo de la regeneración natural de palma chilena (Jubaea chilensis) en el parque nacional la campana, región de valparaíso. Biodiversidata 7, 25-37.

Cabello, A. (2006). "Jubaea chilensis (Mol.) baillon," in Las Especies Arbóreas de los Bosques Templados de Chile y Argentina. Autoecología, ed. C. Donoso (Valdivia: Marisa Cuneo Ediciones).

Campbell, D. J., and Atkinson, I. A. E. (2002). Depression of tree recruitment by the pacific rat (Rattus exulans Peale) on New Zealand's northern offshore islands. Biol. Conserv. 107, 19-35. doi: 10.1016/S0006-3207(02)00039-3

Carroll, C., Noss, R. F., Paquet, P. C., and Schumaker, N. H. (2004). Extinction debt of protected areas in developing landscapes. Conserv. Biol. 18, 1110-1120. doi: $10.1111 /$ cobi. 13308

Corlett, R. T. (2017). Frugivory and seed dispersal by vertebrates in tropical and subtropical Asia: an update. Glob. Ecol. Conserv. 11, 1-22. doi: 10.1016/j.gecco. 2017.04.007

Cusack, J. J., Wearn, O. R., Bernard, H., and Ewers, R. M. (2015). Influence of microhabitat structure and disturbance on detection of native and non-native murids in logged and unlogged forests of northern Borneo. J. Trop. Ecol. 31, 25-35. doi: 10.1017/S0266467414000558

Devenish, A. J. M., Gomez, C., Bridle, J. R., Newton, R. J., and Sumner, S. (2019). Invasive ants take and squander native seeds: implications for native plant communities. Biol. Invasions 21, 451-466. doi: 10.1007/s10530-018-1829-6

Drake, D. R., and Hunt, T. L. (2009). Invasive rodents on islands: integrating historical and contemporary ecology. Biol. Invasions 11, 1483-1487. doi: 10. 1007/s10530-008-9392-1

Echeverría, C., Coomes, D., Salas, J., Rey-Benayas, J. M., Lara, A., and Newton, A. (2006). Rapid deforestation and fragmentation of Chilean temperate forest. Biol. Conserv. 130, 481-494. doi: 10.1016/j.biocon.2006.01.017

Echeverría, C., Newton, A., Lara, A., Rey-Benayas, J. M., and Coomes, D. (2007). Impact of forest fragmentation on species composition and forest structure in the temperate landscape of southern Chile. Glob. Ecol. Biogeogr. 16, 426-439. doi: 10.1111/j.1466-8238.2007.00311.x and wrote the first draft of the manuscript with contributions of SC and FG. All authors read and approved the submitted version.

\section{FUNDING}

SC was supported by a Ph.D. scholarship granted by the Chilean Agency of Research and Development (ANID, 21211752).

\section{ACKNOWLEDGMENTS}

We are grateful to the Chilean Forestry Corporation (CONAF) for granting us access to the study area. We are indebted to Piero Vitta, Gerardo Jara, Franco Verdessi, Javiera Rodríguez, Constanza Andía, Manuel López, and Joaquín Gómez, who assisted in the field and to Hacienda Las Palmas de Cocalán for providing us the seed material for the study. Comments of three reviewers largely improved the manuscript.

Farwig, N., and Berens, D. G. (2012). Imagine a world without seed dispersers: a review of threats, consequences and future directions. Basic Appl. Ecol. 13, 109-115. doi: 10.1016/j.baae.2012.02.006

Figueroa-Esquivel, E., Puebla-Olivares, F., Godinez-Alvarez, H., and NunezFarfan, J. (2009). Seed dispersal effectiveness by understory birds on Dendropanax arboreus in a fragmented landscape. Biodivers. Conserv. 18, $3357-$ 3365. doi: 10.1007/s10531-009-9645-Z

Fleury, M., Marcelo, W., Vásquez, R. A., González, L. A., and Bustamante, R. O. (2015). Recruitment dynamics of the relict palm, Jubaea chilensis: intricate and pervasive effects of invasive herbivores and nurse shrubs in Central Chile. PLoS One 10:e0133559. doi: 10.1371/journal.pone.0133559

Flores-Toro, L., and Aguirre-Saavedra, F. (2008). Riqueza florística del Santuario de la Naturaleza Palmar El Salto, Viña del Mar, Región de Valparaíso, Chile. Gayana Bot. 65, 71-83.

Fontúrbel, F. E. (2012). Does habitat degradation cause changes in the composition of arboreal small mammals? A small-scale assessment in Patagonian temperate rainforest fragments. Lat. Am. J. Conserv. 2, 68-72.

Fontúrbel, F. E., Bruford, M. W., Salazar, D. A., Cortés-Miranda, J., and VegaRetter, C. (2019). The hidden costs of living in a transformed habitat: ecological and evolutionary consequences in a tripartite mutualistic system with a keystone mistletoe. Sci. Total Environ. 651, 2740-2748. doi: 10.1016/j.scitotenv. 20148.10.125

Foster, J. T., and Robinson, S. K. (2007). Introduced birds and the fate of Hawaiian rainforests. Conserv. Biol. 21, 1248-1257. doi: 10.1111/j.1523-1739.2007. 00781.x

Gallardo, H., Bravo, P., and Grimberg, M. (2014). Jubaea chilensis. Santiago: Ministerio del Medio Ambiente.

Gallardo, H., Möder, L., and Benoit, I. (2006). Plan Nacional Para la Conservación y Recuperación de la palma chilena Jubaea chilensis (Mol.) Baillon. Viña del Mar: Corporación Nacional Forestal (CONAF) Región de Valparaíso.

Gomes, L. G. L., Oostra, V., Nijman, V., Cleef, A. M., and Kappelle, M. (2008). Tolerance of frugivorous birds to habitat disturbance in a tropical cloud forest. Biol. Conserv. 141, 860-871. doi: 10.1016/j.biocon.2008.01.007

González, L. A., Bustamante, R. O., Navarro, R. M., Herrera, M. A., and Ibáñez, M. T. (2009). Ecology and management of the Chilean palm (Jubaea chilensis): history, current situation and perspectives. Palms 53, 68-74.

González, L. A., Toral Ibáñez, M., and Navarro, R. M. (2017). Palma Chilena: Una Especie Emblemática que Chile Necesita Recuperar. Santiago de Chile: Minera Los Pelambres - Universidad de Chile.

Guzmán, E., Alcalde, J. A., Contreras, S., and Fernández, M. P. (2017). A review of the massive Chilean palm Jubaea chilensis. Caldasia 39, 183-203.

Hechenleitner, V., Gardner, M. F., Thomas, P. I., Echeverría, C., Escobar, B., Brownless, O., et al. (2005). Plantas Amenazadas del Centro-sur de Chile. 
Santiago de Chile: Universidad Austral de Chile - Royal Botanic Garden Edinburgh.

Holmgren, M., Segura, A. M., and Fuentes, E. R. (2000). Limiting mechanisms in the regeneration of the Chilean matorral-experiments on seedling establishment in burned and cleared mesic sites. Plant Ecol. 147, 49-57. doi: 10.1023/A:1009804726307

Howe, H. F., and Smallwood, J. (1982). Ecology of seed dispersal. Annu. Rev. Ecol. Syst. 13, 201-228. doi: 10.1146/annurev.es.13.110182.001221

Hunt, T. L. (2007). Rethinking Easter Island's ecological catastrophe. J. Archaeol. Sci. 34, 485-502. doi: 10.1016/j.jas.2006.10.003

Kelt, D. A., Meserve, P. L., Nabors, L. K., Forister, M. L., and Gutierrez, J. R. (2004). Foraging ecology of small mammals in semiarid Chile: the interplay of biotic and abiotic effects. Ecology 85, 383-397. doi: 10.1890/02-4065

Lichti, N. I., Steele, M. A., and Swihart, R. K. (2017). Seed fate and decision-making processes in scatter-hoarding rodents. Biol. Rev. 92, 474-504. doi: 10.1111/brv. 12240

Marcelo, W. (2007). Efecto de la Herbivoria, el Microhábitat y el Tamaño de las Semillas en la Sobrevivencia y Crecimiento de Plántulas de la palma chilena Jubaea chilensis (Mol.) Baillon. Ph.D. thesis, Santiago: Universidad de Chile.

Maron, J. L., and Pearson, D. E. (2011). Vertebrate predators have minimal cascading effects on plant production or seed predation in an intact grassland ecosystem. Ecol. Lett. 14, 661-669. doi: 10.1111/j.1461-0248.2011.01633.x

Meadley-Dunphy, S. A., Prior, K. M., and Frederickson, M. E. (2020). Invasive ants disperse seeds farther than native ants, affecting the spatial pattern of seedling recruitment and survival. Oecologia 192, 119-132. doi: 10.1007/s00442-01904553-3

Meyer, W. M., and Shiels, A. B. (2009). Black rat (Rattus rattus) predation on nonindigenous Snails in Hawai'i: complex management implications. Pac. Sci. 63, 339-347. doi: 10.2984/049.063.0304

Miranda, A., Hernández, H., Bustamante, R. O., Díaz, E., González, A., and Altamirano, A. (2016). Natural regeneration and spatial distribution patterns of Chilean palm Jubaea chilensis (Molina) Baillon in Mediterranean forests of Central Chile. Gayana Bot. 73, 54-63. doi: 10.4067/s0717-66432016000100007

Möder, L., Rojas, O., and González, L. A. (1997). Reestudio de los Límites Propuestos Para Creación del área "Palmar El Salto" Como Santuario de la Naturaleza. Informe técnico No15/97. Valparaíso: Corporación Nacional Forestal.

Myers, N., Mittermeier, R. A., Mittermeier, C. G., da Fonseca, G. A. B., and Kent, J. (2000). Biodiversity hotspots for conservation priorities. Nature 403, 853-858. doi: $10.1038 / 35002501$

Perez, H. E., Shiels, A. B., Zaleski, H. M., and Drake, D. R. (2008). Germination after simulated rat damage in seeds of two endemic Hawaiian palm species. J. Trop. Ecol. 24, 555-558. doi: 10.1017/S0266467408005257

Pérez-Méndez, N., Jordano, P., and Valido, A. (2018). Persisting in defaunated landscapes: reduced plant population connectivity after seed dispersal collapse. J. Ecol. 106, 936-947. doi: 10.1111/1365-2745.12848

Pliscoff, P. (2009). "Climatología," in Parque Nacional La Campana: Origen de una Reserva de la Biosfera en Chile Central, eds S. Elórtegui and A. Moreira-Muñoz (Viña del Mar: Taller La Era), 22-26.

Quintanilla, V., Cadiñanos, J., Latasa, I., and Lozano, P. (2012). Aproximación biogeográfica a los bosques de la zona mediterránea de Chile: caracterización e inventario. Boletin de la Asoc. de Geogr. Espanoles 60, 91-114.

Rodríguez-Cabal, M. A., Aizen, M. A., and Novaro, A. J. (2007). Habitat fragmentation disrupts a plant-disperser mutualism in the temperate forest of South America. Biol. Conserv. 139, 195-202. doi: 10.1016/j.biocon.2007.06.014

Saiz, H., and Alados, C. L. (2012). Changes in semi-arid plant species associations along a livestock grazing gradient. PLoS One 7:e40551. doi: 10.1371/journal. pone. 0040551

Serra, M. T., Gajardo, R., and Cabello, A. (1986). Jubaea chilensis. Ficha Técnica de Especies Amenazadas. Santiago de Chile: CONAF- Universidad de Chile.
Shiels, A. B., and Drake, D. R. (2011). Are introduced rats (Rattus rattus) both seed predators and dispersers in Hawaii? Biol. Invasions 13, 883-894. doi: 10.1007/ s10530-010-9876-7

Shiels, A. B., Pitt, W. C., Sugihara, R. T., and Witmer, G. W. (2014). ). Biology and impacts of Pacific Island invasive species. 11. Rattus rattus, the Black Rat (Rodentia: Muridae). Pac. Sci. 68, 145-184. doi: 10.2984/68.2.1

Stachurska-Swakon, A., Barabasz-Krasny, B., Klasa, A., and Palaczyk, A. (2018). Reduced plant fitness by pre-dispersal seed predation in the threatened plant species Cirsium decussatum. Seed Sci. Res. 28, 123-130. doi: 10.1017/ S0960258518000107

Tilman, D., May, R. M., Lehman, C. L., and Nowak, M. A. (1994). Habitat destruction and the extinction debt. Nature 371, 65-66.

Towns, D. R., Atkinson, I. A. E., and Daugherty, C. H. (2006). Have the harmful effects of introduced rats on islands been exaggerated? Biol. Invasions 8, 863891. doi: 10.1007/s10530-005-0421-z

Traveset, A., and Richardson, D. M. (2006). Biological invasions as disruptors of plant reproductive mutualisms. Trends Ecol. Evol. 21, 208-216. doi: 10.1016/j. tree.2006.01.006

Valiente-Banuet, A., Aizen, M. A., Alcantara, J. M., Arroyo, J., Cocucci, A., Galetti, M., et al. (2015). Beyond species loss: the extinction of ecological interactions in a changing world. Funct. Ecol. 29, 299-307. doi: 10.1111/1365-2435. 12356

Vander Wall, S. B. (1990). Food Hoarding in Animals. Chicago IL: The University of Chicago Press.

Vizentin-Bugoni, J., Tarwater, C. E., Foster, J. T., Drake, D. R., Gleditsch, J. M., Hruska, A. M., et al. (2019). Structure, spatial dynamics, and stability of novel seed dispersal mutualistic networks in Hawai'i. Science 364, 78-82. doi: 10.1126/ science.aau 8751

Willson, M. F., Rice, B. L., and Westoby, M. (1990). Seed dispersal spectra-a comparison of temperate plant communities. J. Veg. Sci. 1, 547-562. doi: 10. $2307 / 3235789$

Yabe, T., Hashimoto, T., Takiguchi, M., Aoki, M., and Fujita, M. (2010). Twig cutting by the black rat, Rattus rattus (Rodentia: Muridae), on the Ogasawara (Bonin) islands. Pac. Sci. 64, 93-97. doi: 10.2984/6 4.1.093

Zhang, H. M., Gao, H. Y., Yang, Z., Wang, Z. Z., Luo, Y., and Zhang, Z. B. (2014). Effects of interspecific competition on food hoarding and pilferage in two sympatric rodents. Behaviour 151, 1579-1596. doi: 10.1163/1568539x00003201

Zunino, S., Sáiz, F., and Yates, L. (1992). Habitat use, density of Octodon degu and resource availability in Ocoa, La Campana National Park, Chile. Rev. Chil. Hist. Nat. 65, 343-355. doi: 10.17221/7621-vetmed

Conflict of Interest: The authors declare that the research was conducted in the absence of any commercial or financial relationships that could be construed as a potential conflict of interest.

Publisher's Note: All claims expressed in this article are solely those of the authors and do not necessarily represent those of their affiliated organizations, or those of the publisher, the editors and the reviewers. Any product that may be evaluated in this article, or claim that may be made by its manufacturer, is not guaranteed or endorsed by the publisher.

Copyright (C) 2021 Cordero, Gálvez and Fontúrbel. This is an open-access article distributed under the terms of the Creative Commons Attribution License (CC BY). The use, distribution or reproduction in other forums is permitted, provided the original author(s) and the copyright owner(s) are credited and that the original publication in this journal is cited, in accordance with accepted academic practice. No use, distribution or reproduction is permitted which does not comply with these terms. 